\title{
Eco-Efficiency in Farm Management for Sustainable Agriculture: a Two-Stage Data Envelopment Analysis in Wheat Production
}

\author{
Osman İnanç Güney* \\ Çukurova University, Turkey \\ Received: 16 March 2021 \\ Accepted: 8 May 2021
}

\begin{abstract}
At present, the sensitivity of economic and ecological balances makes resource use more important. In this context, efficiency is at the focal point in the operations of sectors such as agriculture, where the use of unsustainable inputs is intense and the relative added value is low. A two-stage approach is utilized to assess and set a benchmark for the wheat farmers in Adana, Turkey. The first stage analyses wheat farms and uses Data Envelopment Research (DEA) analysis to explore possible areas of performance improvements for inefficiency. The efficiency scores obtained were reduced over a collection of contextual variables in the second stage to classify the possible sources of inefficiency using the Tobit regression model. Required farm management data were collected from 111 wheat farms via face-to-face interviews in March-July 2019. According to the DEA, results mean TE scores are found as 0.883 which means that the sampled wheat farmers could reach full technical efficiency through reducing their input usage by $11.7 \%$ with the current level of technology to produce the same output levels. The results of the Tobit regression model indicate that factors such as farmland ownership, total farm area, and procuring inputs in cash positively influenced the TE, whereas being experienced in wheat farming had a negative effect.
\end{abstract}

Keywords: sustainability, eco-efficiency, agriculture, DEA, Tobit regression

\section{Introduction}

In 1941, a new agricultural reform called the "green revolution" was planned in the United States to meet the increasing food demand of the growing world population as more people live in cities and fewer people farm the land. The Mexican Agricultural

*e-mail: inancguney@gmail.com
Program (MAP) introduced the "miracle wheat" in 1954 and spread throughout Asia and Africa in the 1950s and 1960 s, and the reform continued with other crops like rice and maize $[1,2]$.

The reform has increased agricultural production with the use of new technologies, water management practices, mechanization and inorganic chemicals, and made it possible for farmers to produce more agricultural products at lower costs. However, agrochemical input and natural resource intensification generate the pressure of agriculture on natural resources such as soil 
pollution and degradation, groundwater contamination, air pollution and greenhouse gas emissions [3, 4]. Moreover, in connection with the law of diminishing returns, there is no linear relationship between using more production factors and obtaining more output. Several scientific studies have shown that even with a reduction in input use, it is possible to sustain crop production and efficiency in agriculture [5].

The dispute between agriculture and the environment is becoming increasingly troublesome, and to cope with the lack of resources and the fragile ecological environment, traditional agricultural practices need to be modernized [6]. Sustainable agricultural practices aim to reduce these environmental costs while ensuring food safety for the present and future generations [7-9]. Therefore, effective resource use is necessary to minimize the depletion of resources that contribute to agricultural sustainability and eco-efficiency [10].

Cereal production is a major activity in the agricultural sector, wherein $45 \%$ of today's economically active population is engaged [11-14]. Wheat (Triticum aestivum L.) is one of the most produced cereals and staple foods (730 million tons in 2015) and is cultivated extensively throughout the world on a larger scale than any other crop [15-19].

Since the beginning of the "green revolution" in the 1950s, wheat production has undergone a significant transformation, and the global wheat yield has grown by an average of $2.5 \%[2,13,20]$. Wheat productivity has significantly increased over the last century due to improved varieties, mechanization, more effective disease control, and improved farm management practices [21]. Along with the increase in wheat yield, there has been an increase in production costs, especially in recent years, due to the continued increase in energy prices and production input costs. It is expected that the implication of climate change will also increase wheat irrigation costs, particularly in the next period $[13,20,22]$.

The efficient production capacity of farmers as decision-making units (DMUs) is crucial when evaluating their economic performance and competitiveness in the agricultural sector [23]. To achieve profitability conditions in agricultural production, it is important to maximize efficiency at farm levels [24]. Therefore, measuring efficiency as the first step of improvement in the agriculture industry is an important task to evaluate the performance of DMUs for both theorists and agro-policy makers [25]. Also, the close relationship between agricultural production and the environment measures efficient use of resources an important subject of experimental research [26]. In order to research the trade-offs between the input of productive resources and the sustainability of the agriculture sector, an analysis of the eco-efficiency of wheat production is important. In the 1990s, the idea of eco-efficiency was introduced to measure sustainability in agriculture by describing the ratio of economic value added by crop production to environmental consequences [6]. The goal of this definition is to bring the economic and environmental dimensions together to connect manufacturing to environmental impacts: delivering more value while using fewer resources [27]. Eco-efficiency in agriculture refers to the production of high-quality products while reducing the use of inputs such as land, water, energy, labor and capital [4].

Data Envelopment Analysis (DEA) is a nonparametric efficiency estimation technique developed by [28], which is considered to be the most important method for allocating resources and measuring the relative efficiency of DMUs [10, 29, 30]. This technique has the potential to predict resource usage and relative efficiency of DMUs based on their performance. It also has the advantage of measuring the efficiency of multiple inputs and/or outputs using linear programming for aggregating different environmental impacts to construct a comprehensive eco-efficiency indicator [27, 29-31]. DEA is a common tool for evaluating the agricultural sector and helping to identify how effectively a farmer can produce a certain level of output by applying to other farmers the levels of available input resources [3, 30, 10].

For sustainable agricultural production, it is important to analyze and predict production efficiency to reveal the effective use of agricultural resources in order to generate the highest possible output [10]. In this study, efficiency measurement of the input use in wheat production and the determinants of the inefficiency situation was investigated by using

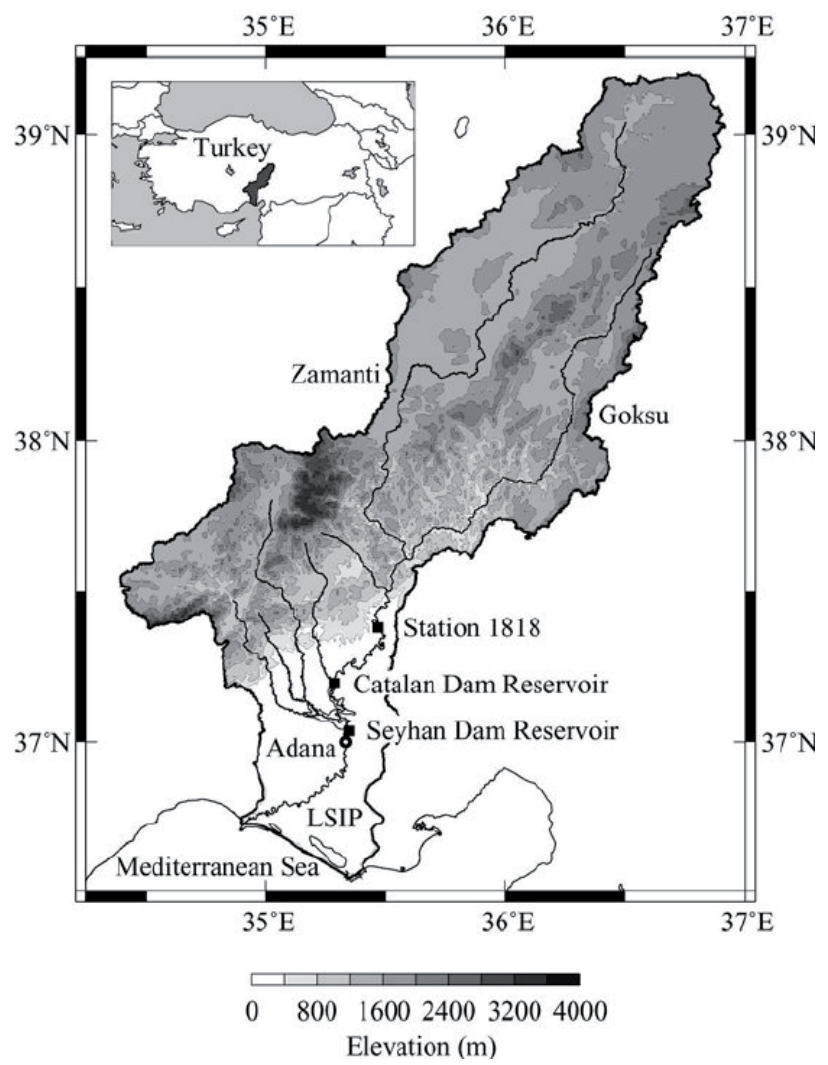

Fig. 1. Research area [37]. 
the DEA and Tobit regression models. Thus, it can understand how well the sector or unit of production performs in the use of resources to produce wheat and what is the environmental costs of the wheat production [32]. Input use plays a fundamental role in increasing environmental impacts in wheat agriculture and identifying possible ways to reduce these inputs as environmental factors will be able to achieve ecoefficiency and clean production in agriculture and wheat farming [33]. The study suggests best practices that can help increase technological productivity in the production of wheat and help boost the profitability and output of the sector [31].

\section{Materials and Methods}

\section{Data Collection and Survey Area}

In this study, the analysis was based on primary data collected through a field survey of 111 wheat farms in the lower Seyhan plain of Adana City, Çukurova Region, that were chosen via random sampling. The face-to-face survey was conducted by a commercial research and marketing agency (Ayna Market Research Co.) during April-August 2019.

Çukurova is one of the largest coastal plains in Turkey, and agriculture is the major land use in the region [34]. Wheat is one of the most produced crops in the region, with a production level of 1.311.123 tons. Adana, which is the largest city of Çukurova plain, produces 52\% (681.905 tons) of the region's wheat production alone [35]. The wheat production is mainly operating in lower Seyhan basin in Adana City and this basin performs the earliest wheat harvest in Turkey. In the area, wheat is produced as the main product, though it can also be produced with secondary products such as soy, corn, peanut, and cotton [36].

The data constitute of inputs used per ha of wheat production including seed (£/ha.), fertilizer (‡/ha.), pesticides (€/ha.), labor (€/ha.), mechanization ( $\mathrm{min} / \mathrm{ha}$.) and fuel (Lt/ha.) while the gross production of wheat (TL/ha) was the single output.

\section{First Stage: Eco-Efficiency Measurements}

In order to increase efficiency, it is necessary to know where to invest in order to ensure eco-efficiency

Table 1. Sociodemographic structure of the sampled wheat farms.

\begin{tabular}{|c|c|c|c|c|c|}
\hline & Frequency & $\%$ & & Frequency & $\%$ \\
\hline Age of the farmers & & & Education of the farmers & & \\
\hline $36<$ & 15 & 13.5 & Illiterate & 1 & .9 \\
\hline $36-50$ & 36 & 32.4 & Literate & 1 & .9 \\
\hline $51-65$ & 51 & 45.9 & Primary school & 66 & 59.4 \\
\hline $65>$ & 9 & 8.1 & High school & 35 & 31.5 \\
\hline Total & 111 & 100 & University & 8 & 7.2 \\
\hline Household no. & & & Total & 111 & 100 \\
\hline $4<$ & 49 & 44.1 & Residence & & \\
\hline $4-6$ & 42 & 37.8 & Farm & 81 & 73 \\
\hline $7-9$ & 14 & 12.6 & Town & 22 & 19.8 \\
\hline $9>$ & 6 & 5.4 & City center & 3 & 2.7 \\
\hline \multirow[t]{2}{*}{ Total } & 111 & 100 & Mixed & 5 & 4.5 \\
\hline & & & Total & 111 & 100 \\
\hline Farmland ownership & & & Years in agriculture & & \\
\hline Own property & 88 & 78.4 & $11<$ & 8 & 7.2 \\
\hline Rental & 23 & 16.2 & $11-20$ & 15 & 13.5 \\
\hline Total & 111 & 100 & $21-30$ & 24 & 21.6 \\
\hline Coop. member & & & $31-40$ & 40 & 36 \\
\hline Yes & 48 & 43.2 & $41-50$ & 20 & 18 \\
\hline No & 63 & 56.8 & $50>$ & 4 & 3.6 \\
\hline Total & 111 & 100 & Total & 111 & 100 \\
\hline
\end{tabular}


and regain competitiveness. Determining the efficiency/ inefficiency of an organization and identifying the reasons for its performance contribute to creating strategies for the sector [31].

[25] investigated the structure and measurement of productive efficiency and defined the technical efficiency as a measure to identify firm efficiency which reflects the ability of a farm to produce the maximum possible output from a given set of inputs or to produce the given level of output by a minimum input usage with a given technology $[25,38]$.

Based on [25] previous work, the DEA model was developed by [ 28] as an empirical frontier analysis technique [ 38,24$]$. It is a useful decision-making tool and one of the most frequently used methods among the nonparametric linear programming methods in the literature on-farm efficiency measurements [39-41].

Since 1978, DEA has been widely used in a wide variety of segments of society, including banks, hospitals, transportation, education and the agriculture sector [31]. The advantage of the DEA method, unlike other econometric approaches this method requires no initial assumptions about specifying the involved production function as well as the standard errors [10].

Technical Efficiency (TE) of a DMU is a comparative measure of how well it processes inputs to achieve its outputs, hence the main performance indicator in agricultural production. It can be used to determine and increase to optimize the performance of the productive units where they need to improve their efficiency concerning the use of inputs [31, 42]. The DEA method calculates the frontier production function of a set of DMUs and evaluates the relative TE of each production unit by estimating the frontier output given the physical input quantities and chosen production characteristics [41, 43-45].

The DMUs are referred to as technically efficient with a score of "1", while those below the frontier are accepted as inefficient with a score of less than " 1 " [24, 45].

The DEA model can be defined as,

$$
\begin{aligned}
& \text { Min } 0, \lambda \quad \theta \text {, subject to } \\
& \text {-yi }+\mathrm{Y} \quad \lambda \geq 0 \\
& \theta \mathrm{Xi}-\mathrm{X} \quad \lambda \geq 0 \\
& \text { N1' } \lambda=1 \\
& \lambda \geq 0
\end{aligned}
$$

...where:

Xi: input vector of the DMUs to be analyzed

yi: output vector of the DMUs to be analyzed

$\theta$ : efficiency score of the $\mathrm{i}^{\text {th }}$ unit

$\lambda: \mathrm{N} x 1$ vector of constants

Y: output matrix

$\mathrm{X}$ : input matrix

a change in inputs is

In the current study, an input-oriented DEA model under the Variable Return to Scale (VRS) situation seemed appropriate because wheat farms have more control over input levels than output levels and a change in inputs expected to result in a disproportionate change in outputs [42, 45]. The input-oriented analysis is becoming more common in DEA applications because profitability depends on the efficiency of the operators and Variable Returns to Scale (VRS) analysis is more flexible and envelops the data more tightly than the Constant Returns to Scale (CRS) [42]. Using inputoriented DEA models to estimate the TE enabled the measurement of how much the number of inputs could be reduced in a farm while maintaining the same output level $[38,46]$.

\section{Second Stage: Tobit Regression Model}

Although the DEA calculates the efficiency, this approach is not able to examine the factors that cause inefficiency. To overcome this problem, a regression model is applied as a second stage to estimate a linear relationship between the effect of a set of independent variables and the efficiency results of the DEA results. In general, the Tobit regression model is utilized to explain the inefficiency in production. The Tobit model was first presented by Tobin (1958) to describe the relationship between a non-negative dependent variable $\mathrm{y}$ and independent variables [46-48]. In this research, the TE scores obtained from the DEA ranging between 0 and 1 were accepted as the dependent variables, and the farm-specific attributes were accepted as the independent variables [38, 40, 46, 48].

The model can be represented as follows:

$$
\begin{gathered}
y^{*}=\mathrm{X} \beta+\varepsilon, \\
\mathrm{y}=\mathrm{y}^{*} \text { if } \mathrm{y}^{*} \geq 0, \\
\mathrm{y}=0 \text { if } \mathrm{y}^{*}<0, \\
\text { with } \varepsilon \sim \mathrm{N}(0, \sigma 2)[47]
\end{gathered}
$$

\section{Results and Discussion}

In the current study, the input usage and output performance of the sampled wheat producers were obtained to create a DEA model in order to measure the efficiency situation and determine the environmental costs. Following this, factors affecting the efficiency or inefficiency levels were estimated by associating possible independent variables that could affect production with a level of efficiency model by Tobit model.

The descriptive statistics of the input and output variables associated with the surveyed farms are given in Table 2. The high variation coefficient of mechanization usage indicated it was the least correctly used input and not properly managed by the wheat farms. Besides, the highest expenditure of wheat farms per ha. was determined as the fertilizer use. The mean gross production value of the wheat farms was calculated as 4824.6 Turkish Lira (£) per ha. 
Table 2. Descriptive statistics of the input and output variables of the surveyed farms.

\begin{tabular}{|c|c|c|c|c|c|}
\hline Variable & Mean & Min & Max & Std. Deviation & Coef. of Variance \\
\hline \multicolumn{7}{|c|}{ Output } \\
\hline Gross prod. (TL/ha.) & 4824.6 & 279.00 & 760.00 & 102.97 & 21.34 \\
\hline \multicolumn{7}{|c|}{ Inputs } \\
\hline Seed (£/ha.) & 422.8 & 110.0 & 750.0 & 101.8 & 240.8 \\
\hline Fertilizer (£/ha.) & 888.1 & 192.5 & 1535.0 & 282.2 & 317.8 \\
\hline Pesticides (£/ha.) & 396.4 & 65.0 & 1120.0 & 183.3 & 462.4 \\
\hline Labor (£/ha.) & 356.8 & 93.0 & 1270.0 & 213.0 & 593.0 \\
\hline Mechanization (min/ha.) & 519.9 & 100.0 & 1650.0 & 383.0 & 736.7 \\
\hline Fuel (Lt/ha.) & 77.7 & 250 & 192.0 & 33.3 & 428.6 \\
\hline
\end{tabular}

1 lt. fuel: 6.68 €

Table 3 presents the summary of the TE scores measured with the input-oriented DEA method of the surveyed wheat farms under CRS, VRS, and Scale efficiency (SE) conditions. The mean TE scores under CRS were 0.762 and ranged from 0.319 to 1 , whereas the mean TE scores under VRS were 0.883 and ranged from 0.629 to 1.000 . Besides, the mean SE score was measured as 0.858 . From these results, the 33 farms under CRS and 58 farms under VRS had a TE score greater than 0.90. The DEA under VRS assumption results reflects that only about $50 \%$ of the wheat farms were operating under efficiency conditions.

In previous studies, similar input-oriented $\mathrm{TE}$ analysis results have been obtained regarding wheat production in Turkey. [49] applied DEA analysis on bread wheat production in Kahramanmaraş province to 111 producers and estimated the mean efficiency score as 0.972 under VRS. [50] estimated the TE score as 0.83 under VRS conditions in their study on wheat farms operating in Adiyaman province.

In similar international studies on efficiency measurements for wheat farms, [46] calculated the efficiency score of 124 wheat enterprises in Uzbekistan under VRS conditions as 0.82. Meanwhile, [48] calculated the activity score as 0.93 in Pakistan with the DEA method. [51] developed a DEA model for Czech wheat production and delivered TE result of 0.835 . In their studies on efficiency measures of wheat farming in western great plains in the USA, [52] estimated the average TE score as 0.65 . [53] reported the results of DEA estimation for wheat production in the Republic of Serbia as 0.77 . In another study by [54], the mean TE score for wheat crop using DEA was estimated as 0.668 in Pakistan. [55] employed the DEA model in Kermanshah province of Iran to wheat farmers and calculated the mean efficiency score as 0.86 .

In previous studies on the TE score calculated under CRS conditions in wheat production, the following results were obtained: [38] calculated 0.71 in Tunisia, [46] determined 0.79 in Uzbekistan, [48] observed 0.76 in Pakistan, and [40] calculated 0.85,7 in Bangladesh. All these studies demonstrated that the efficiency levels under CRS are smaller than those under VRS due to size differences in the DMUs, leading to a scale ineffectiveness [56].

The DEA results also summarized the performance of each analyzed input for wheat production (Table 4) to determine which input was used in what efficiency condition. According to Table 4, the most inefficient input usage concerned the wheat farms' mechanization use, with 35\% excess usage. Excess usage also occurred for labor use (13.5\%). In line with this argument, [51] also points to the lower human capital use in their study. Ineffective labor use was also observed in the wheat

Table 3. Distribution of the efficiency scores of the surveyed farms.

\begin{tabular}{|c|c|c|c|}
\hline Efficiency Scores & CRS & VRS & SE \\
\hline 1.00 & 20 & 31 & 22 \\
\hline $0.90-1.00$ & 13 & 27 & 31 \\
\hline $0.80-0.90$ & 17 & 23 & 25 \\
\hline $0.70-0.80$ & 18 & 17 & 15 \\
\hline $0.60-0.70$ & 17 & 13 & 11 \\
\hline $0.60-0.50$ & 18 & 0 & 6 \\
\hline$<0.50$ & 8 & 0 & 1 \\
\hline Mean & 0.762 & 0.883 & 0.858 \\
\hline Minimum & 0.319 & 0.629 & 0.497 \\
\hline Maximum & 1 & 1 & 1 \\
\hline IRS (\%) & & & 72 \\
\hline DRS (\%) & & & 8.2 \\
\hline CRS (\%) & & & 19.8 \\
\hline
\end{tabular}

IRS: Increasing Returns to Scale; DRS: Constant Returns to Scale; CRS: Constant Returns to Scale 
Table 4. Excess input usage for wheat production.

\begin{tabular}{|c|c|c|c|c|}
\hline Inputs & Farms & Average Slack & Average Input Usage & Excess Input Use (\%) \\
\hline Seed (£/ha.) & 22 & 15.95 & 422.8 & 3.77 \\
\hline Fertilizer (£/ha.) & 9 & 23.61 & 888.1 & 2.65 \\
\hline Pesticides (£/ha.) & 40 & 48.67 & 396.4 & 12.2 \\
\hline Labor (£/ha.) & 25 & 48.17 & 356.8 & 35.5 \\
\hline Mechanization (min/ha.) & 60 & 182.44 & 519.9 & 10 \\
\hline Fuel (lt./ha.) & 34 & 07.78 & 77.7 & 35 \\
\hline
\end{tabular}

efficacy analysis studies of [40] (30.24\%). Another variable subject to excess input was pesticide use (12.2\%). [40] also reported pesticide use ineffectiveness in their study (28.95\%). Various other inputs were not operating effectively and had excess use: fuel (10\%), seed (3.77\%), and fertilizer (2.65\%). [51] and [52] also reported the excess use of fuel and fertilizer in their studies. [54] point to the high use of fuel and fertilizers for wheat farming in Pakistan.

Moreover, the SE results from the DEA showed that $72 \%$ of the wheat farms were operating under IRS conditions. In their study, [38] reached similar conclusions and calculated that $71.7 \%$ of the wheat farms in their research area were operating under IRS conditions. In the remaining enterprises, approximately $20 \%$ were working under CRS, while only $8 \%$ were under DRS.

The current study investigated the possible reasons for the detected inefficiency conditions using a Tobit regression model. Table 5 presents the model results.

According to the Tobit regression model, the years in agriculture, farmland ownership, field size, and input supply method variables were related to the wheat farms' efficiency/inefficiency performance. There was an inverse relationship between the increase in agricultural experience in wheat farming and farm efficiency $(p>0.020)$. As the time spent in wheat agriculture increased, productivity decreased, and vice versa. However, [48] found a positive relationship between experience and technical activity.

The results also show that there was a positive relationship between farmland size and productivity ( $p>0.007)$. Accordingly, as the farmland size increased, the probability of producing more effectively also increased. This relationship was also identified in studies of [53], [52] and [38] which were concluded that as farm size increases, the efficiency level increases.

In the surveyed area, some farmlands were acquired from the farmer's property, while others were rented, which affected the efficiency. Farmers renting their fields produced more effectively than those who owned their property $(p>0.026)$. A similar negative impact of farmland ownership on TE was found in a study by [57] and [52].

Another variable that determined efficiency was the input procurement method. The efficiency of those receiving cash inputs was higher than that of those receiving futures, i.e., the more advanced the farmers received the inputs, the more their efficiency increased.

Table 5. Tobit regression model results.

\begin{tabular}{|c|c|c|c|c|c|c|}
\hline Variables & Coefficients & $\mathrm{SE}$ & $\mathrm{t}$ & $\mathrm{p}>|\mathrm{t}|$ & \multicolumn{2}{|c|}{$95 \%$ conf. interval } \\
\hline Years in agriculture & -.0012362 & .0005219 & -2.37 & $0.020 * *$ & -.0022712 & -.0002011 \\
\hline Household size & .0069491 & .0059215 & 1.17 & .0243 & -.0047949 & .018693 \\
\hline Residence & -.000203 & .0131094 & -0.02 & 0.988 & -.0262025 & .0257964 \\
\hline Farmland ownership & .0565652 & .0250428 & 2.26 & $0.026^{* *}$ & .0068988 & .1062316 \\
\hline Total area (farmland size) & .0000256 & .000009 & 2.76 & $0.007^{*}$ & .0000071 & .000044 \\
\hline Wheat area & -.000544 & .000062 & -0.88 & 0.382 & -.0001773 & .0000686 \\
\hline Input supply & -.0379831 & .0204635 & -1.86 & $0.066^{* * *}$ & -0.785677 & .0026015 \\
\hline Constant & .8704927 & .039598 & 21.98 & 0.000 & .7919594 & .949026 \\
\hline \multicolumn{2}{|c|}{ Log likelihood: } & 84.154 & prob $>$ F: & 0.0000 & & \\
\hline
\end{tabular}

$*, * *, * * *$ are $1 \%, 5 \%$ and $10 \%$ significance levels, respectively. 


\section{Conclusions}

It is a fact that although the "green revolution" has positive effects on meeting the increasing global food demand, it also increases the pressure of agriculture on the environment. Since food production cannot be reduced to solve this problem, the only alternative should be to support environmentally friendly sustainable production methods that reduce the negative effects of agriculture (Gołaś et al.).

The implementation of a sustainable production model in the agricultural sector can only be possible by preserving the ecological balance. In this context, sustainability in the agricultural sector depends on the existence of eco-efficiency production models (Gołaś et al.). The eco-ineffectiveness is caused by excessive and unplanned input use, and the demonstration of this situation can reveal very important results in achieving sustainability targets in agriculture.

In this report, since it is one of the key agricultural activities worldwide, wheat agriculture is acknowledged as a model. Thus, the environmental effects of the excessive inputs used in this agricultural operation can be considered to be more inclusive. For a similar strategy, there is a common feature of extrinsic factors (independent variables) that cause inefficiency.

Results of the DEA model demonstrated that the sampled wheat farmers are operating at the technical efficiency level of $88.3 \%$ under VRS conditions. This represented an inefficiency situation and an environmental cost, as the producers would still reach the same output level if their inputs were reduced by $11.7 \%$.

In the research area, although there an inefficiency situation is existing on average, the DEA results showed that approximately $30 \%$ of the enterprises were operating under full efficiency conditions and that around $70 \%$ of the sampled farms' efficiency levels were above 0.90 (high-scale efficiency). Thus, it could be concluded that the majority of farms were operating at or close to full-scale efficiency.

Since the DEA analysis could determine which input was used efficiently in the production, the input elements causing inefficiency in wheat production could be emphasized. In this context, it was observed that the highest rate of inefficient use among the inputs used in production was in mechanization (35\% excess), which may have been caused by outdated mechanization usage in agricultural production in the region. The high inefficiency result of the analysis for fuel usage also supported this situation (10\% excess). Besides, there was a high level of labor use inefficiency. The low level of education of the agricultural workers and the fact that they do not see farming as a profession are the main reasons for the ineffectiveness of the use of the labor force. Farmers often use high amounts of pesticides to reduce the risk of pests, which can lead to negative ecological effects.
Within the research scope, the factors causing inefficiency in the wheat farms were also examined and the steps to improve the activity environment were determined. The parameter estimates showed that factors such as farmland ownership, total farm area, and procuring inputs in cash positively influenced the efficiency situation, whereas being experienced in wheat farming had a negative effect.

As a result of the small scale of wheat farms, many businesses operate under IRS conditions, and their efficiency would increase if the wheat farms worked at larger scales. The Tobit model showed that there is a positive relationship between farmland size and TE in wheat production.

Another factor determining the level of effectiveness in wheat production was farmland ownership. The more farmland leased for use, the higher the level of effectiveness. This situation has arisen from the fact that in cases where farmland ownership has passed through previous generations and there is no cost for farmland ownership, a more disorganized production occurs compared to those paying rent for the farmland.

Moreover, in the research results, a negative relationship was determined between experience and the effectiveness level, indicating that young and new wheat farmers have started to produce more effectively.

The fact that the research was conducted in a limited area (lower Seyhan basin) this situation can be considered as a limitation. Similar researches can be operated in other wheat cultivated regions of Turkey that have different production characteristics to make comparisons.

\section{Acknowledgements}

This research was derived from the FBA-202012972 project, which was supported by the Scientific Research Projects Unit of the University of Çukurova, Turkey.

\section{References}

1. LLEWELLYN D. Does global agriculture need another green revolution? Engineering. 4 (4), 2018.

2. PATEL R. The Long Green Revolution. The Journal of Peasant Studies. 40 (1), 2013.

3. EXPÓSITO A., VELASCO F. Exploring environmental efficiency of the European agricultural sector in the use of mineral fertilizers. Journal of Cleaner Production. 253 (2020), 2020.

4. GOŁAŚ M., SULEWSKİ P., WÁS A., GAJEWSKA A.K., POGODZIŃSKA K. On the way to sustainable agriculture-eco-efficiency of Polish commercial farms. Agriculture. 10 (10), 2020.

5. ZULFIQAR F., DATTA A., THAPA G.B. Determinants and resource use efficiency of "better cotton": An innovative cleaner production alternative. Journal of Cleaner Production. 166 (2017), 2017. 
6. ZHONG F., JIANG D., ZHAO Q., GUO A., ULLAH A., YANG X., CHENG Q., ZHANG Y., DING X. Ecoefficiency of oasis seed maize production in an arid region, Northwest China. Journal of Cleaner Production. 268 (2020), 2020.

7. BONGIOVANNI R., LOWENBERG-DEBOER J. Precision agriculture and Sustainability. Precision Agriculture, 5, 2004.

8. BRODT S., SIX J., FEENSTRA G., INGELS C., CAMPBELL D. Sustainable agriculture. Nature Education Knowledge. 3 (10), 1, 2011. https://www. nature.com/scitable/knowledge/library/sustainableagriculture-23562787/. (Accessed 25 March 2020).

9. OECD. Agriculture and the environment. Better policies to improve the environmental performance of the agriculture sector, 2020. https://www.oecd.org/agriculture/ topics/agriculture-and-the-environment/. (Accessed 10 September 2020).

10. NANDY A., SINGH P.K. Farm efficiency estimation using a hybrid approach of machine learning and data envelopment analysis: Evidence from rural eastern India. Journal of Cleaner Production. 267 (2020), 2020.

11. SALDIVAR S. Cereal grains. The Staff of Life. in: Cánovas, G. (Eds.), Cereal Grains Properties, Processing, and Nutritional Attributes, Boca Raton, 1, 2010.

12. SARWAR M.H., SARWAR M.F., SARWAR M., QADR N.A., MOGHAL S. The importance of cereals (Poaceae: Gramineae) nutrition in human health: A review. Journal of Cereals and Oilseeds. 4 (3), 2013.

13. SHIFERAW B., SMALE M., BRAUN H., DUVEILLER E., REYNOLDS M., MURICHO G. Crops that feed the world 10. Past successes and future challenges to the role played by wheat in global food security. Food Security. $\mathbf{5}$ (3), 2013.

14. XUE W., HAN Y., TAN J., WANG Y., WANG G., WANG $\mathrm{H}$. Effects of nanochitin on the enhancement of the grain yield and quality of winter wheat. Journal of Agricultural and Food Chemistry. 66 (26), 2018.

15. ARNADE C., VOCKE G. Seasonal variation in the price discovery process of international wheat. Agribusiness. 31 (1), 2016.

16. KOBATA T., KOÇ M., BARUTÇULAR C., TANNO K., INAGAKI M. Harvest index is a critical factor influencing the grain yield of diverse wheat species under rainfed conditions in the Mediterranean zone of southeastern Turkey and northern Syria. Plant Production Science. 21 (2), 2018

17. POPESCU A. Maize and wheat - top agricultural products produced, exported and imported by Romania. Scientific Papers Series Management, Economic Engineering in Agriculture and Rural Development. 18 (3), 2018.

18. SOARE E., CHIURCIU I.A. Research on the Romanian wheat market. Scientific Papers Series Management, Economic Engineering in Agriculture and Rural Development. 16 (2), 2016.

19. ZIOLKOWSKA J., JECHLITSCHKA K., KIRSCHKE D. Global implications of national price policies on the wheat market-quantitative assessment of world market effects. Agricultural Economics (AGRICECON). 55 (10), 2009.

20. XU Z., YUA Z., ZHAO J. Theory and application for the promotion of wheat production in China: past, present and future. Journal of the Science of Food and Agriculture. $\mathbf{9 3}$ (10), 2013.

21. DIXON J., NALLEY L., KOSINA P., ROVERE R.L., HELLIN J., AQUINO P. Adoption and economic impact of improved wheat varieties in the developing world. Journal of Agricultural Science. 144 (6), 2006.

22. DIXON J., BRAUN H.J., CROUCH J. Overview: Transitioning wheat research to serve the future needs of the developing world. In: Dixon, J., Braun, H.J., Crouch, J. (Eds.), Wheat Facts and Futures 2009, Mexico. 1, 2009.

23. GIANNAKAS K., SCHONEY R., TZOUVELEKAS V. Technical efficiency, technological change and output growth of wheat farms in Saskatchewan. Canadian Journal of Agricultural Economics. 49 (12), 2001.

24. KELLY E., SHALLOO L., GEAIY U., KINSELLA A., WALLACE M. Application of data envelopment analysis to measure technical efficiency on a sample of Irish dairy farms. Irish Journal of Agricultural and Food Research. 51 (1), 2012.

25. FARRELL M.J. The measurement of productive efficiency. Journal of the Royal Statistical Society Series A. 120 (3), 1957.

26. ALI K.M.E., SAMAD Q.A. Resource use efficiency in farming: An application of stochastic frontier production function. Journal of Agricultural Economics and Development. 2 (5), 2013.

27. MASUDA K. Measuring eco-efficiency of wheat production in Japan: a combined application of life cycle assessment and data envelopment analysis. Journal of Cleaner Production. 126 (2016), 2016.

28. CHARNES A., COOPER W.W., RHODES E. Measuring the efficiency of decision making units. European Journal of Operational Research. 2 (6), 1978.

29. AL-MEZEINI N.K., OUKIL A., AL-ISMAILI A.M. Investigating the efficiency of greenhouse production in Oman: A two stage approach based on Data Envelopment Analysis and double bootstrapping. Journal of Cleaner Production. 247 (2020), 2020.

30. BANDBAFHA H.H., PELESARAEI A.N., KHANALI M., GHAHDERIJANI M., CHAU K. Application of data envelopment analysis approach for optimization of energy use and reduction of greenhouse gas emission in peanut production of Iran. Journal of Cleaner Production. 172 (2018), 2018.

31. DUARTE A., SALGADO JR A.P., LEMOS S.V., SOUZA JR M.A.A., ANTUNES F.A. Proposal of operating best practices that contribute to the technical efficiency in Brazilian sugar and ethanol mills. Journal of Cleaner Production. 214 (2019), 2019.

32. DJOKOTO J.G., FRANCIS Y., SROFENYOH F.Y., ARTHUR A.A.A. Technical inefficiency effects in agriculture-a meta-regression. Journal of Agricultural Science. 8 (2), 2016.

33. PELESARAEI A.N., RAFIEE S., MOHTASEBI S.S., BANDBAFHA H.H., CHAU K. Energy consumption enhancement and environmental life cycle assessment in paddy production using optimization techniques. Journal of Cleaner Production. 162 (2017), 2017.

34. ALPHAN H., YILMAZ T. Monitoring environmental changes in the Mediterranean coastal landscape: the case of Çukurova, Turkey. Environmental Management. 35 (5), 2005.

35. TURKISH STATISTICAL INSTITUTION (TUIK). Wheat production statistics, 2018. https://biruni.tuik.gov. $\mathrm{tr} /$ medas $/$ ?kn=92\&locale $=\operatorname{tr}$. (Accessed 20 March 2020).

36. KEKLIKÇI Z. Determination of suitable seed quantities in sprinkling wheat cultivation after four different pre-plants in Çukurova. Anadolu Journal of Aegean Agricultural Research Institute. 8 (2), 1998. 
37. FUJIHARA Y., SIMONOVIC S., TOPALOĞLU F., TANAKA K., WATANABE T. An inverse-modelling approach to assess the impacts of climate change in the Seyhan River basin, Turkey. Hydrological Sciences Journal. 53 (6), 2008.

38. CHEBIL A., FRIJA A., THABET C. Economic efficiency measures and its determinants for irrigated wheat farms in Tunisia: a DEA approach. New Medit. 14 (2), 2015.

39. BATTESE G.E., NAZLI H., SMALE M. Factors influencing the productivity and efficiency of wheat farmers in Punjab, Pakistan. Journal of Agribusiness in Developing and Emerging Economies. 7 (2), 2017.

40. KAMRUZZAMAN M., MANOS B. The technical efficiency of wheat farms in Bangladesh: a nonparametric analysis. Outlook on Agriculture. 38 (4), 2009.

41. REGO M.A.S., SABBAG O.J., SOARES R.B, PEIXOTO S. Technical efficiency analysis of marine shrimp farming (Litopenaeus vannamei) in biofloc and conventional systems: A case study in northeastern Brazil. Anais da Academia Brasileira de Ciências. 90 (4), 2018.

42. AVVAL S.H.M., MOHAMMADI A., RAFIEE S., TABATABAEEFAR A. Assessing the technical efficiency of energy use in different barberry production systems. Journal of Cleaner Production. 27 (2012), 2012.

43. JHA R., CHITKARA P., GUPTA S. Productivity, technical and allocative efficiency and farm size in wheat farming in India: a DEA approach. Applied Economics Letters. 7 (1), 2000.

44. MCDONALD J., Efficiency in the Domesday economy, 1086: evidence from Wiltshire estates. Applied Economics. 42 (25), 2010.

45. MISRA J., MISRA S.R. Technical efficiency of fish farms in west Bengal: nature, extent and implications. Agricultural Economics Research Review. 27 (2), 2014.

46. SHERZOD B., KIM K.R., LEE S.H. Agricultural transition and technical efficiency: an empirical analysis of wheat-cultivating farms in Samarkand region, Uzbekistan. Sustainability. 10 (9), 2018.

47. MOFFITT R.A. New Developments in Econometric Methods for Labor Market Analysis. In: Ashenfelter, O and Card, D (Eds). Handbook of Labor Economics, vol. 3A, Handbook in Economics 5, North-Holland, 1999.
48. MIRZA F.M., NAJAM N., MEHDI M., AHMAD B. Determinants of technical efficiency of wheat farms in Pakistan. Pakistan Journal of Agricultural Sciences. 52 (2), 2015.

49. CANDEMIR S. Energy use and efficiency analysis in bread wheat production: case of Kahramanmaraş province. Turkish Journal of Agriculture and Natural Sciences. 7 (4), 2020.

50. ALEMDAR T., ÖREN N. Determinants of technical efficiency of wheat farming in southeastern Anatolia, Turkey: a nonparametric technical efficiency analysis. Journal of Applied Sciences. 6 (4), 2006.

51. CURTISS J., JELÍNEK L. Cost efficiency and farm selfselection in precision farming: the case of Czech wheat production. In:131 st EAAE Seminar 'Innovation for Agricultural Competitiveness and Sustainability of Rural Areas', Prague, Czech Republic, 2012.

52. VITALE P.P., VITALE J., EPPLIN P. Factors affecting efficiency measures of Western Great Plains wheat dominant farms. Journal of Agricultural and Applied Economics. 51 (1), 2019.

53. POPOVIĆ R., KOVLJENIĆ M. Efficiency of wheat production in republic of Serbia. Economics of Agriculture. 64 (4), 2017.

54. ILAHI S., WU Y., RAZA M.A.A., WEI W., IMRAN M., BAYASGALANKHUU L. Optimization approach for improving energy efficiency and evaluation of greenhouse gas emission of wheat crop using data envelopment analysis. Sustainability. 11 (2019), 2019.

55. ABDI R., SHAHAMAT E.Z., HEMATIAN A., MOBTAKER H.G. Optimization of energy required for wheat production in Kermanshah province of Iran, International Journal of Agriculture: Research and Review. 3 (2), 2013

56. ULU Ö., ENGINDENIZ S., ÖZDEN A. Analysis of input usage efficiency in okra production in İzmir Province. Turkish Journal of Agricultural Economics. 22 (2), 2016.

57. ADHIKARI C.B., BJORNDAL T. Analyses of technical efficiency using SDF and DEA models: evidence from Nepalese agriculture. Applied Economics. 44 (25), 2012. 